\title{
Politics, Society and Financial Liberalization: Turkey in the 1990s
}

\author{
Ümit Cizre-Sakallıŏglu and Erinç Yeldan
}

\begin{abstract}
This article focuses on the political economy of Turkey in the 1990s to illustrate the importance of analysing economic variables that intersect with the quality of political democracy. In 1989, the debt-ridden state moved to systematically and completely deregulate Turkey's financial markets. Together with the ongoing processes of liberalizing commodity markets and integrating with global capital markets, financial liberalization was expected to achieve fiscal and monetary stability, stimulate business confidence to invest in productive sectors, produce stable growth, encourage privatization and control inflation. However, the new hegemony of the capital markets has gone handin-hand with deteriorating macroeconomic performance, a worsening income distribution, the discrediting of politics and its isolation from society. The authors examine several key dynamics which are helping to legitimate the neoliberal agenda of the 1990s. These include the distribution of state largesse to manipulate electoral capitalism; the rise of an informal sector in the 'Anatolian Tigers'; promotion of the seductive attractions of the market; and an antipolitical reform populism adopted by political actors to exploit popular disillusionment with the political system.
\end{abstract}

\section{INTRODUCTION}

Turkey's post-1980 neoliberal model has suffered persistent problems. As the 1990s draw to a close, the most striking aspect of Turkey's political economy is the elevation of its economic agenda to the status of 'secularism', that is to a level linked to the existence and sustainability of the regime. At the time of writing, in 1999, there is a new sense of alarm and urgency in the discourses of the civilian and military bureaucracy and the political class about the need for discipline in the government's fiscal management. One source of this new thinking is the rising power of pro-Islamic ideology, represented until very recently by the Welfare Party (WP - Refah Partisi),

We are grateful to Irma Adelman, Selcuk Caner, Bilin Neyapti, Hakan Berument, Izak Atiyas, Menderes Çinar, Fikret Şenses, Oktar Türel and two anonymous referees of this journal for their critical comments and suggestions. None of them, however, bears any responsibility for the views and arguments set forth in this article.

Development and Change Vol. 31 (2000), 481-508. (C) Institute of Social Studies 2000. Published by Blackwell Publishers, 108 Cowley Road, Oxford OX4 1JF, UK. 
which was banned by the Constitutional Court in January 1997. The proIslamic political agenda is seen as directly addressing the issues of worsening income distribution and social equity, and it was largely this which led the then-Prime Minister, Mesut Yllmaz ${ }^{1}$ to caution that if the fight against inflation fails and distributional injustice continues, conservation of the regime will turn into a grave problem'. ${ }^{2}$ It was in this context that Yilmaz and his economic bureaucracy presented their economic package for 1998 as a milestone for the 'survival of the regime', 'protection of the social peace' and 'integration into the European Union as a full member' ${ }^{4}$ President Süleyman Demirel shares the paralysing fear of the political class of a possible 'social explosion' based on the erosion of the middle class due to the destructive impact of high inflation. ${ }^{5}$

This official state line highlights the conceptual problem facing the regime with regard to political and economic modernization - the dramatic gap between the expected gains from market-led growth and the lacklustre results that have been achieved so far. The issue is whether this disappointing performance is largely due to deviations from stabilization policy objectives, or to 'the inherent difficulties with the neoliberal structural adjustment model, at least in the Turkish setting' (Boratav et al., 1996: 391). Or is it, as Offe (1997: 35) argues for the East European transformation into a market economy, a result of 'the dilemma of simultaneity'? Offe holds that what is emerging in Eastern Europe is a form of 'politically incorrect capitalism' which has no historical precedent in the West, where market economy and democracy grew simultaneously. This is a political capitalism in which policies that are designed to liberalize the economy are also likely to produce frictions, inequalities, uncertainties and discontinuities, and are attempted in conditions of weak democratic legitimacy. The result is that:

democratic rights must be held back to allow for a healthy dose of original accumulation ... it is possible that the majority of the population will find neither democracy nor a market economy a desirable project ... then we are presented with a Pandora's box of paradoxes, in the face of which every theory — or, for that matter, rational strategy — of the transition must fail. (Offe, 1997: 41)

1. The minority coalition government including the centre-left Democratic Left Party (Demokratik Sol Parti) and led by Mesut Yilmaz, the leader of the centre-right Motherland Party (MP - Anavatan Partisi) collapsed on 25 November 1998 when Yllmaz lost a vote of confidence in parliament over the allegation that he had rigged the sale of a state bank to a Mafia-connected businessman. Before the government was brought down, however, the parliament had decided to hold early elections on 18 April 1999.

2. 'Yilmaz'dan Rejim Uyarısı' (Warning by Y1lmaz on the Regime), Milliyet, 5 December 1997.

3. Ibid.

4. 'Yılmaz: Yatırımlar Ertelenecek' (Yılmaz: Investments Will Be Postponed), Hürriyet, 12 November 1997.

5. 'Sosyal Patlama Olabilir: Dikkat' (Beware of a Social Explosion), Milliyet, 10 February 1998. 
Yllmaz showed his awareness of this dilemma during his term in office, when he is quoted as saying: 'compared to developed countries, Turkey stands at a disadvantaged position: it does not, for instance, have an unemployment insurance and therefore job-security scheme. Under such conditions, measures to fight against inflation will produce extremely serious social implications, will pose a threat to employment prospects and cause stagnation in the economy'. ${ }^{6}$

This may fit the facts of the Turkish case, with its frustrations at neoliberal reform, broken promises in the past, and the new realization that sustainable growth may actually be induced by improving the distribution of income, rather than vice versa. However, the more fundamental question from a political economy perspective is the political and ideological underpinning of Turkey's market-supporting reforms of the 1990s. The main aim of this study, therefore, is not just to evaluate the effects of Turkey's phases of economic liberalism on politics and society, but to trace the extent to which the elements of 'political' calculus and choice/design that are embedded in the liberal model have significantly changed during this period. Our second objective is to understand the 'political' sustainability of pro-market approaches in this period by looking at the political sites of legitimation both inside and outside the country.

Our analysis of the interface between political conditions and the pursuit of economic policies acknowledges that markets do not command automatic legitimacy; rather, policies will be considered legitimate only in so far as the forms that they take and the ways that they operate are acceptable to the people politically, ethically, culturally, and economically. Theoretically, we view legitimacy as consisting of two facets: on one level, it relies on 'distinctively political and/or ideological aspects of the state (such as the rule of law, electoral accountability or national-popular support)'; on another level 'it also depends on a flow of material concessions whose long-term stability depends on promoting accumulation' (Jessop, 1990: 216). Consideration of the political sustainability of neo-liberalism in the 1990s will therefore necessarily involve measuring the performance of the political and economic order as well.

The discussion is organized in four parts. In the first section we provide an overview of the political-economic foundations of the 1990s - the so-called financial revolution. Next, we study the income distribution consequences of this socio-economic polity and examine the dynamics of the public sector in the economy, and its role in the discourse of Turkish politics. The state, society, and politics under distributional deterioration are then analysed, while the final section focuses on the political mechanisms through which neoliberal ideas and practices are legitimated and sustained by the state in the 1990s.

6. 'Yllmaz'dan Rejim Uyarıs' (Warning by Y1lmaz on the Regime), Milliyet, 5 December 1997. 


\section{ECONOMIC FOUNDATIONS OF THE 1990S: THE 'FINANCIAL REVOLUTION'}

Turkey's attempts to liberalize its financial system so as to integrate with global financial markets began in 1980. The earlier system had been rife with the attributes of 'financial repression', with negative real interest rates, a heavy tax burden on financial earnings, and high liquidity and reserve requirement ratios. Capital transactions were completely liberalized and the Turkish lira was made fully convertible in 1989. This single move represents a watershed in Turkey's post-1980 neoliberalism in terms of the choices it reflected and their impacts on politics, economy and society.

In retrospect, one can say that financial reforms progressed in leaps and bounds, mostly through pragmatic, in situ solutions to emerging problems. ${ }^{7}$ The financial liberalization reform was expected to result in a more efficient and flexible financial system, capable of converting national savings into productive investments at the lowest cost. This expectation led to a strong emotional commitment and a stance of non-reversibility of the course of reform. Contrary to expectations, however, the reforms were not accompanied by any significant change in the financing behaviour of the corporations and did not lead to a cheapening of investment costs (Akyüz, 1990). The government maintained its dominance in both the commodity and the asset markets through a complex system of price and fiscal incentives. The real rate of interest in fact rose to unprecedented levels; domestic asset markets, impacted by sudden changes in speculative foreign capital flows, became volatile and uncertain, culminating in the complete breakdown of the financial system in 1994, and ultimately resulting in a severe economic crisis.

The volatile character of post-financial liberalization economic growth in Turkey, with its mini boom-and-bust cycles, is evident from Table 1. The rate of growth of GDP was meagre in 1988 and 1989, increased to 7.9 per cent in 1990, but then fell back to 1.1 per cent in 1991, continuing to fluctuate thereafter. Concomitant with this trend was the cyclical behaviour of consumption and investment. Public investment expenditures were ideologically held to a downward trend; private investments trends, on the other hand, were unstable. Private capital accumulation peaked in 1993 at 35 per cent, then immediately contracted in 1994 to -9.1 per cent. The overall expansion of private capital accumulation was modest and could not provide a sustained stimulus to the overall economy.

Table 1 also reveals growing imbalances in foreign trade. By the end of the 1980s exports financed, on average, 70 per cent of the volume of imports. After 1990 this ratio declined rapidly to 58 per cent, and stayed at about that level until 1993. In 1993, just before the financial crisis broke, the

7. For a thorough account of the financial reform, see Atiyas (1995); Balkan and Yeldan (1998); Boratav et al. (1996); Yeldan (1997); Yentürk (1996). 
Table 1. Main Economic Indicators, Turkey, 1988-1998

\begin{tabular}{|c|c|c|c|c|c|c|c|c|c|c|c|}
\hline & 1988 & 1989 & 1990 & 1991 & 1992 & 1993 & 1994 & 1995 & 1996 & 1997 & 1998-I \\
\hline \multicolumn{12}{|l|}{ Annual \% Change } \\
\hline GDP & 2.7 & 1.2 & 7.9 & 1.1 & 5.9 & 8.0 & -5.5 & 7.2 & 7.0 & 6.7 & 7.2 \\
\hline \multicolumn{12}{|l|}{ Consumption } \\
\hline Private & 1.2 & -1.0 & 13.1 & 1.9 & 3.3 & 8.4 & -5.3 & 4.8 & 8.5 & 8.0 & 7.1 \\
\hline Public & -1.1 & 0.8 & 7.9 & 4.5 & 3.8 & 2.3 & -3.5 & 6.8 & 8.6 & 4.1 & 8.4 \\
\hline \multicolumn{12}{|l|}{ Fixed investments } \\
\hline Private & 12.6 & 1.7 & 19.4 & 0.9 & 4.3 & 35.0 & -9.1 & 16.9 & 12.1 & 11.7 & 5.6 \\
\hline Public & -20.2 & 3.2 & 8.9 & 1.8 & 4.3 & 3.4 & -34.8 & -18.8 & 24.4 & 28.4 & 30.0 \\
\hline Exports (millions US\$) ${ }^{\mathrm{a}}$ & 11929 & 11780 & 13026 & 13667 & 14891 & 15611 & 18390 & 21637 & 23225 & 26245 & 6459 \\
\hline Imports (millions US\$) ${ }^{\mathrm{a}}$ & 14335 & 15792 & 22302 & 21047 & 22871 & 29428 & 23270 & 35709 & 43626 & 48585 & 11188 \\
\hline Current account (m US\$) ${ }^{\mathrm{a}}$ & 1596 & 961 & -2625 & 250 & -974 & -6433 & 2631 & -2339 & -5380 & -4739 & -1248 \\
\hline \multicolumn{12}{|l|}{ Ratios to the GNP (\%): } \\
\hline Financial value added & 3.3 & 2.9 & 3.2 & 4.1 & 4.0 & 4.3 & 3.0 & 4.2 & 5.0 & 5.1 & 9.2 \\
\hline Budget balance & -3.0 & -3.3 & -3.1 & -5.3 & -4.3 & -6.7 & -3.9 & -4.0 & -8.2 & -7.3 & -11.1 \\
\hline PSBR & 4.8 & 5.2 & 7.4 & 10.3 & 10.6 & 12.1 & 7.9 & 5.4 & 9.6 & 8.2 & 8.0 \\
\hline Stock of domestic debt & 5.7 & 6.3 & 7.0 & 8.1 & 11.7 & 12.8 & 14.0 & 14.6 & 18.8 & 21.4 & 22.0 \\
\hline Interest payments on domestic debt & 2.4 & 2.2 & 2.4 & 2.7 & 2.8 & 4.6 & 6.0 & 6.2 & 9.0 & 7.7 & 10.8 \\
\hline Inflation rate $(\mathrm{CPI}, \%)$ & 75.4 & 64.3 & 60.4 & 71.1 & 66.1 & 71.1 & 106.3 & 88.0 & 80.4 & 85.7 & 97.2 \\
\hline Real exchange rate ${ }^{\mathrm{b}}$ & 101.5 & 96.2 & 82.6 & 84.7 & 88.5 & 88.5 & 114.9 & 102.9 & 104.2 & 104.0 & 104.3 \\
\hline Real interest rate on government bonds ${ }^{\mathrm{c}}$ & -5.8 & -2.7 & -4.0 & 5.3 & 13.9 & 9.9 & 28.6 & 18.1 & 31.1 & 22.1 & 6.2 \\
\hline \multicolumn{12}{|l|}{ Index of employment in private } \\
\hline manufacturing & 100.0 & 98.6 & 95.2 & 79.5 & 78.1 & 80.3 & 75.5 & 82.9 & 89.1 & 94.4 & 94.3 \\
\hline $\begin{array}{l}\text { Index of real wages in private } \\
\text { manufacturing }\end{array}$ & 100.0 & 144.1 & 152.0 & 205.2 & 210.0 & 208.0 & 147.2 & 156.3 & 172.5 & 160.5 & 157.9 \\
\hline
\end{tabular}

Source: SPO Main Economic Indicators; SPO, Ekonomik ve Sosyal Gostergeler (1950-1997).

(a) Excluding luggage trade.

(b) Index, $1987=100$. Derived from the basket with weights, $0.75 \$+0.25 \mathrm{DM}$; deflated by the wholesale price index. An increase means depreciation of the Lira.

(c) Annual average of Compounded Interest Rate on Government Debt Instruments deflated by the CPI.

(d) Index $(1988=100)$ based on index of production workers' hourly wages in Private Manufacturing industry, deflated by the CPI (seasonally adjusted). 
export/import ratio dropped to 53 per cent, causing the current account deficit to widen, reaching US\$ $6.4 \mathrm{bn}$. The current account balance turned to a surplus in 1994 due to a severe decline in import demand. Once the crisis had been overcome, however, import demand recovered, and the current account deficit began to widen again, to US\$ 4.4 bn.

One sign of the vulnerability of Turkish macroeconomic balances in this period was continued inflation. Price inflation, as measured by the annual change in the consumer price index, was around 60-65 per cent in the second part of the 1980s. After 1991, this increased to about 70 per cent. The post-crisis period (after 1994) saw a further acceleration, with inflation in the 80-90 per cent range during 1995-9. The prolonged volatility of the economy, with failed business expectations and consequent shifts in real incomes of the working masses, inevitably contributed to a continued decline in the political realm and to the erosion of legitimacy of the democratic institutions as a whole.

\section{The Dominant Processes of the Post-Financial Reform}

Throughout this period, Turkey's banking and financial institutions were disengaging from production to become the dominant forces behind the capital manipulating the overall economy. This development was driven by both domestic and global factors. On the domestic side, the collapse of public disposable income led to a fever of public sector borrowing. The consequent high interest rates on government bonds and treasury bills set a course for the dominance of finance over the real economy. As a result, the economy became trapped in a vicious circle, with commitment to high interest rates and cheap foreign currency (overvalued Turkish lira), against the threat of capital flight, leading to further increases in real interest rates. At times of excessive destabilization of the current account balance, real depreciation seems imminent, and has to be matched by further upward adjustment in the rate of interest if currency substitution or capital flight are to be restrained. This process, as in the case of Mexico in 1995, and the recent crises of East Asia, leads to overvaluation of the domestic currency, cheapening of imports, and thus an acceleration of domestic consumption at the expense of exports and productive industries in general. Instability in rates of foreign exchange and interest rates feed back into further instability in the economy as a whole (Boratav et al., 1995: 21).

The global dimension of the rising prominence of finance was no less important. As the Turkish state intensified the process of internationalization, it also became directly accountable to external asset markets. ${ }^{8}$ The

8. Turkey's foreign debt is around $\$ 80 \mathrm{bn}$, one of the highest in the world when considered against $\$ 30$ bn of domestic debt (SPO Main Economic Indicators). 
judgements of global capital markets became the ultimate arbiters of the government's creditworthiness. Complete deregulation of the finance sector, Turkish-style, brought in through the backdoor the power of veto on domestic policies by international asset-holders, whose primary concern was not the long-term development prospects of domestic production, but immediate financial gain. The crisis of 1994, in hindsight, showed the vulnerability of the Turkish economy to speculative gains of 'hot money' and 'casino capitalism' (Strange, 1986). The fourth quarter of 1993, when currency appreciation and the consequent current account deficit reached unprecedented levels, ${ }^{9}$ was the culmination of this period of fragility in Turkey. With the sudden drain of short-term funds at the beginning of January 1994, production capacity contracted, and industrial output fell continuously throughout that year.

As 'one of the seven countries in the OECD to have the least number of restrictions on capital account transactions' (Kumcu, 1997: 31), Turkey provides an object lesson: that 'the growth of the financial sector should not be an objective in itself, but rather, should be structured to serve the growth of production and investment volumes, and to help sustain the balances of the real sector' (Yentürk, 1997: 4). The ongoing crisis in the financial markets of Southeast Asia testifies to the catastrophic results of relying on international finance, even under conditions of high growth rates and sound macroeconomic foundations over the past two decades, 'with lack of government insight in a deregulated financial system that ran amok' (Richburg and Mufson, 1998).

The promotion of financial liberalization was a conscious choice by the Turkish state, structured according to the logic of globalizing capitalism. The telecommunications and financial sectors were singled out as privileged sectors because of their dynamism in speeding up the global centralization of influence over domestic policies. When we shift the focus to the political implications of the hegemony of the financial sectors, however, the issue becomes entangled with the distributional impact of this hegemony.

\section{ECONOMICS OF THE PUBLIC SECTOR AND DISTRIBUTIONAL STRESS}

\section{Dynamics of Wage-Cycle and the Post-Crisis Adjustment}

Interaction between economics and politics depends not only on overall growth performance but also on who gains and who loses from growth. It is therefore necessary to identify the primary beneficiaries of the post-1989 shift. As shown above, this shift gave way to a new modality of capitalist

9. Observe from Table 1 that the real exchange rate appreciated by 20 per cent between 1988 and 1993. 
accumulation which tightened the global/local nexus by relying on domestic financial markets. Yet, the dramatic expansion of international capital mobility has not led to greater investment and employment opportunities by either foreign investors or the private sector in Turkey. On the contrary, post-1990 data point to a further shrinkage of real wages, decreasing employment opportunities and worsening of income shares for the poorest groups: 'Over the past three decades, 20 per cent of the households with the highest income have managed to receive 50 per cent and more of the total disposable income, while the remaining 80 per cent of households have had to be satisfied with 50 per cent or less' (Kasnakoglu, 1997: 58). Income distribution data are tabulated in Table 2.

In private manufacturing, which is the leading export sector of the economy, employment generation was meagre and declining over the post1988 period (see Table 1). By the second quarter of 1998, the employment index was about 10 per cent below its level of 1988. Wage labour is observed to suffer the major repercussions from the adjustment process in employment and production. The real sector of the domestic economy continued to operate under the imperatives of an unregulated financial sector, and its disequilibria could have only been accommodated by the massive flexibility displayed by the real remunerations of wage labour.

Data in Table 1 which deal with the dynamics of the industrial wage rate suggest three sub-periods: first, 1988-91, when real wages underwent a significant upward adjustment, which technically ended the long-term downslide of wage labour, a process which left its mark on the 1980s. In a sense, the hike in the real wage rate from 1988 signalled that the ongoing structural adjustment based on suppressing of domestic incomes was no longer feasible, politically or economically. From 1991 to late 1993, real wages were generally stable. This relative stability was short-lived, however, given the

Table 2. Distribution of Income Across Households

\begin{tabular}{lcc}
\hline & \multicolumn{2}{c}{ Share In Aggregate Disposable Income } \\
\cline { 2 - 3 } Percentiles & $\mathbf{1 9 8 7}$ & $\mathbf{1 9 9 4}$ \\
\hline Lowest $20 \%$ & 5.23 & 4.86 \\
$21 \%-40 \%$ & 9.61 & 8.62 \\
$41 \%-60 \%$ & 14.07 & 12.60 \\
$61 \%-80 \%$ & 21.16 & 19.02 \\
Highest $20 \%$ & 49.93 & 54.88 \\
Memo: & & \\
Lowest $10 \%$ & 1.94 & 1.84 \\
Highest $10 \%$ & 34.02 & 40.51 \\
$\quad$ Lowest $5 \%$ & 0.70 & 0.69 \\
$\quad$ Highest $5 \%$ & 23.01 & 30.34 \\
\hline
\end{tabular}

Sources: State Institute of Statistics, Income Distribution Surveys, 1987 and 1994; Ekonomist, 28 June 1997. 
consequences of the 1994 crisis. Post-crisis management, starting at the end of 1993, was directly aimed at reducing wages in real terms. The index of the real wage rate in private manufacturing fell by an aggregate of 25 per cent between 1993 and 1998.

\section{The Role of Fiscal Debt as a Regulator of Income Distribution}

Turkey's 'financial reform' became instrumental in aggravating a ballooning public sector debt and turning the government into the country's largest source of inflation. Over the period 1990-6, public disposable income declined by 45 per cent in real terms (UTFT, Main Economic Indicators). ${ }^{10}$ This decline, which was mostly due to the sizeable increase in the salaries of civil servants and the hike in transfer expenditures, had devastating effects and generated strong pressures on the public sector borrowing requirement (PSBR).

After the introduction of new financial instruments, the state found it much easier to finance its borrowing requirements from domestic sources, by issuing government debt instruments. This enabled successive governments to bypass many of the legal regulations and protocols constraining their fiscal operations. One direct consequence of this switch to domestic borrowing was the unprecedented rise in the stock of securitized debt. Stock of government's debt instruments (GDIs) represented about 6 per cent of the GNP in 1989, when liberalization of the capital account was completed. From then on, it grew rapidly, reaching more than 20 per cent by 1998 (see Table 1).

The fragility of the domestic asset markets quickly gave way to very high rates of real interest. The real rate of return offered on the government's debt instruments exceeded comparable market rates on demand deposits by a margin of almost 20 per cent. Interest payments as a ratio of GNP increased very rapidly, reaching 11 per cent in 1998. By contrast, the aggregate share of value added of the agricultural sector in GNP was only 15 per cent in the same year. Thus, interest payments reached more than two-thirds of value added from agriculture, a sector which accounts for about half the active labour force.

Under such conditions, management of fiscal debt may be viewed as an income transfer mechanism, transferring income away from wage-labour and the peasantry, to domestic 'rentiers'. ${ }^{11}$ During the pre-reform, importsubstitution industrialization period, the state was simultaneously a productive

10. See Yeldan (1998) for a more formal account of the deterioration of the fiscal balances of the Turkish public sector in the 1990s.

11. We use this concept here in the light of its common parlance in the Turkish political and economic jargon. Although not a well-defined technical term, the 'rentier' type of income is understood to cover those claims on GNP where appropriations by the claimant are far in excess of its contributions to the production process. 
and a regulatory agent - a producer through its operation of the state enterprise system, and a regulatory agent, in that it was directly involved with the administration of foreign exchange, and the setting of key prices in industry and energy. It also had a direct role in setting the income distribution patterns of the economy. After the reform, however, the state ceased to be either a productive or investing agent; but it continued to play a regulatory role in income redistribution through the conduct of its fiscal operations. The extent of this regulation becomes evident when we look at the taxes imposed on capital incomes. Figure 1 illustrates this point: a comparison of the interest costs of the state and its tax earnings from corporate capital incomes reveals the extent of income transfer accruing to the rentiers through the fiscal debt management of the treasury. The contribution of corporate incomes to aggregate tax revenues lies well below the income captured through interest earnings on the domestic debt, which means that capital incomes in Turkey are effectively untaxed, and the current mode of domestic debt management works as a direct income transfer to the holders of capital income. The state plays an active role in regulating this transfer.

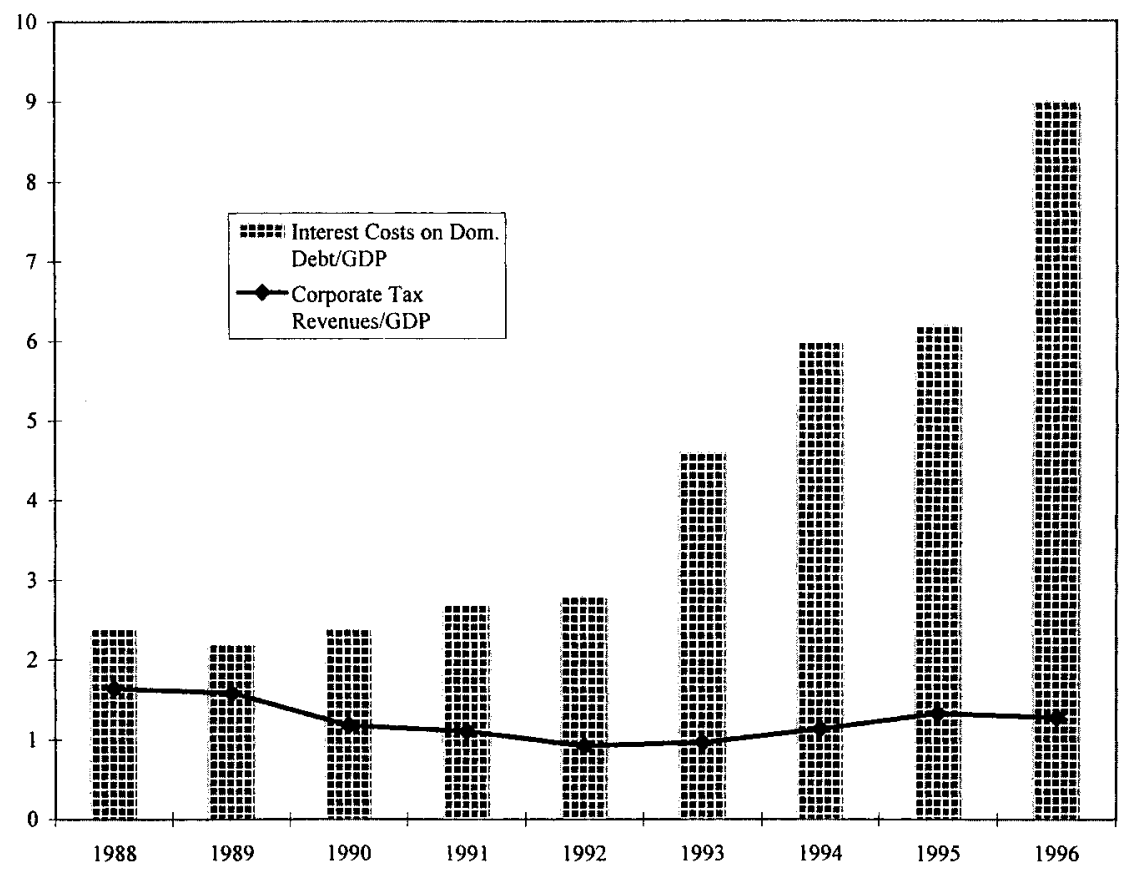

Source: Treasury Monthly Statistics.

Figure 1. Interest Payments on Domestic Debt and Corporate Tax Revenues (\% of GNP) 
The long-debated tax reform was announced by the Y1lmaz government on 6 February 1998. Among its major components were: (i) an overall reduction of tax rates for different income brackets; (ii) an expansion of the tax base to include financial income; and (iii) the granting of new tax amnesties. The tax rate for the highest income bracket was reduced by 15 per cent, and for lower brackets by 10 per cent. Two tax amnesties were granted, one on the stocks of merchandise held by commercial enterprises, and one on the undeclared value of all assets held by individuals.

The aim of the latter measures was to encourage individuals to declare their asset holdings, financial or otherwise, so that the tax coverage could be expanded. Another motive behind the reform seems to have been an implicit supply-side expectation that lowering tax rates would enhance economic activity by encouraging the private sector's entrepreneurial ability. This expansion, in turn, would increase economic growth and hence aggregate tax revenues. The Yilmaz government hailed the reform package as the 'Milad of Turkish Public Finance', arguing that a new dawn was breaking. However, there is no sound evidence to support claims that the elasticity of aggregate tax revenues with respect to national output exceeds unity by a sufficient margin to overcome the initial decline in the tax rates through an expansion in total income. In fact, the experience of the USA under Reagan shows the opposite: with comparable tax cuts in the early 1980s, the Reagan administration actually generated an ever-expanding stock of domestic debt, unparalleled in US peace-time economic history. ${ }^{12}$

Thus, contrary to such naïve expectations, future Turkish fiscal deficits may be expected to rise significantly, increasing the size of the public debt. The current burden of interest costs on the budgetary balances of the central government is already severely felt. As a percentage of GNP, central government budget deficits rose from 3.0 per cent in 1988 , to 8.5 per cent in 1998. Even more alarmingly, as much as 68 per cent of the expected tax revenues of the proposed budget for 1999 is projected to be claimed by interest costs on the already accumulated public debt. This contrasts with OECD figures, in which an average of 75 per cent of all tax revenues are calculated to finance public expenditures on health and education (see, for example, IMF Financial Statistics; Oyan, 1997: Tables 1 and 2). In downsizing the public sector in the real sectors of the economy, the role of the state in shaping the course of development seems to have been forgotten in the Turkish economy of the 1990s. We will now look at the social and political aspects of this economic impasse, and investigate the implications of this distributional deterioration in terms of 'lack of governance' and 'withering of politics'.

12. On the political and economic implications of accelerating US domestic debt in the 1980s, see, for example, Verbon and van Winden (1993), and the contributions by Barro, Bernheim, and Eisner to a symposium held by the Journal of Economic Perspectives (1989). 


\section{STATE, SOCIETY AND POLITICS UNDER DISTRIBUTIONAL DETERIORATION}

Direct parallels can be drawn between the post-1994 crisis mode of adjustment in the Turkish economy and the earlier phase of structural adjustment in 1980-7, in which adjustment was based on suppression of the real earnings of wage labour and high inflation taxation. In both periods, the state assumed an active role as a regulatory agent, overseeing the distributional conflict over the national product. And in both periods, the fiscal operations of the state bore the major brunt of adjustment in resolving the distributional conflict in favour of capital-owners.

Plummeting real wages, the explosion of the informal (unrecorded) economy, and the ensuing distributional stresses in social life, find their starkest expression in the contrasting lifestyles of the urban poor and the rich coexisting in the cities. Alienated, weakly integrated, resentful and struggling to survive on a daily basis, the marginalized masses live on the poverty line in big metropolitan areas. According to a recent report, the richest 18,000 families in Istanbul, who constitute just 1 per cent of the city's population, receive US\$6 bn of the US\$20 bn income generated in the city. The annual income of the poorest family in Istanbul is US\$700; that of the richest family, living a few streets away, is estimated to be around US\$1 million. ${ }^{13}$ While the rich live in grandeur in housing complexes with their own sports and social amenities, send their children to the West to study, attend special health care centres and invest capital in global enterprises, the have-nots line up to buy subsidized bread which, in most cases, constitutes the bulk of their daily diet. ${ }^{14}$

The economic and cultural divide within the metropolitan areas is mirrored by pronounced regional disparities as well as by urban-rural, secular-Islamist, Turkish-Kurdish divisions in the country. The ongoing armed conflict between the state security forces and the Kurdish Workers Party (PKK) has had negative effects on the economy and on politics, and has exacerbated regional imbalances in the distribution of socio-economic and political resources. According to one recent study, per capita income of the poorest city in the southeast, the region where the armed confrontation with the PKK is taking place, 'is only one eleventh of that of an industrial center in the West ... The region uses only 10.2 per cent of the regional income ... the difference between Kocaeli in the West, the city which has the highest GNP per capita in Turkey, and Mus, (in the southeast), which has the lowest, is 1 to 11' (Sonmez, 1998: 29). Some 30 per cent of the region's population

13. Perihan Çakıroğlu, 'Ihtişam ve Sefalet Kucak Kucağa' (Grandeur and Poverty Side by Side), Milliyet, 12 January 1998.

14. Perihan Çakıroğlu, 'Ucuz Ekmeğin Öldüren Cazibesi' (The Fatal Attraction of Cheap Bread), Milliyet, 13 January 1998. 
has migrated to the coastal regions in the south and western metropolitan areas, forming Kurdish ghettos in and around towns and cities there (ibid.: 29).

A social structure characterized by extreme polarization of incomes and lifestyles is clearly not conducive to 'a social pact or a more formal corporatist pact designed to build a consensus around an anti-inflationary strategy' (Öniş, 1997b: 37). Even the President of the Istanbul Chamber of Commerce thinks that the problem of income distribution is a 'time-bomb ticking away': 'At this juncture, the Turkish private sector sees one thing ... it goes out of the interior of the house and feels disturbed by the street. Because when one begins to take interest in the street, different pictures emerge. You are comfortable inside and when you go out, the society with its problems and stresses bothers you'. ${ }^{15}$

What sets the 1990s apart from the previous adjustment era is not just the deterioration of income distribution and the social antagonisms this generates. Although distributional stresses have become worse, they are a legacy of the post-1980 strategies of market management. The resultant problems of fragmentation of society, social violence, weakening of integrative mechanisms, creation of two distinct societies, public corruption, and reliance on conservative policies to unite the torn social fabric of the country have existed in varying degrees over the last decade and a half. Nor is the Turkish case an aberration: there are no clear signs in any struggling democracies that neoliberal policies can deliver sustainable growth which will justify inequalities by leading to better equity for 'larger' numbers of people. Those who gain in one phase may fare less well in the next, as the sudden collapse of the export-bourgeoisie of the 1980s and the hegemony of a globally-integrated financial bourgeoisie in the 1990s have demonstrated. The consistent feature of Turkish neoliberalism, however, is the persistent inability of the economic system to improve the lot of the great majority, while it continues to guarantee the accumulation of massive fortunes for a narrow, albeit changing, circle of winners.

\section{Withering of Politics}

What distinguishes politics as it unfolds in the 1990s against the background of such distributional deterioration, is a paradoxical development in the relationship between state and society: while the impulse of the 'civil society' to engage in public life to express its grievances has grown, the insulation of the state from popular pressures has grown even further. In the language of

15. Murat Sabuncu, interview with Hüsamettin Kavi, the President of Istanbul Chamber of Industry, 'Sokaktaki Manzara İşadamını Ürkütüyor' (The Scene in the Street Alarms the Businessman), Milliyet, 14 January 1998. 
the recent wave of literature on the public sphere, ${ }^{16}$ despite the 'illusion' of a clamorous civil society, one cannot talk of an effective 'public/political sphere' which can subject governments to democratic control. In other words, the existence of a civil society per se does not ensure that there is effective scrutiny and criticism of public affairs by citizens which then resonates inside the political/public sphere. Just as markets are more open and some sectors of the economy are globally competitive, there is now a more openly expressed dissent and debate in civil society. Countless parliamentary investigatory committees have been set up in the 1990s to investigate alleged abuses in state apparatuses. Almost every day, the media draws attention to human rights violations and public corruption, and highlights social poverty, violence and crime. The opposition parties themselves denounce and challenge political irregularities. Nevertheless, apart from elections, the ability of societal actors to evoke governmental responsiveness or accountability is virtually nil. More importantly, Turkey's political class does not just resist, ignore or fail to resolve the explosive social and political problems. Rather, it often operates 'in defiance' of widespread public demands. ${ }^{17}$

The weakness of Turkey's public/political sphere goes hand in hand with the isolation of the political class from the rest of society. The institutional restructuring of Turkish political life after the last military coup of 1980 is a fundamental source of this disconnection between the state and society. In the early 1980s, Turkey's labour market was deregulated and its unions were politically marginalized in line with the dominant orthodoxy. Since the 1980 s, corporatist and party networks of representation that had linked labour to the political sphere throughout much of the Republic's history were demolished in order to let the free-market principle apply to the

16. The public sphere is defined by Jurgen Habermas (1989) as a site of informed deliberation of citizens on public affairs. The concept of a public sphere is important in order to go beyond formal features of political participation. This way, emphasis shifts to the quality of democracy. The difficulty with the concept, however, arises from its presupposition of the 'informed' nature of citizens. The degree to which deliberations in the public sphere are informed and rational is conditioned by a whole range of factors.

17. A good example of this defiance to public pressure is the issue of the absolute power and control held by political party leaders as to whose names are put forward as candidates, and at what position on the list. Reforming election procedures to make candidate selection more democratic, through the introduction of primaries, has gained the support of the public. This forms part of a growing public demand to democratize the internal structure of parties which are characterized by unconditional loyalty to the leader. There is now a broad public consensus that the leader-based features of Turkish political parties are not just symptoms but also contributory causes of the political malaise. Lack of internal democracy in political parties is conceived as retarding the representative and responsive character of the regime by undermining participation, competition, creative ideas, and ethics. Despite the public pressure, however, it was clear that party leaders were determined to enter the elections in April 1999 with the existing system intact, retaining their absolute control over candidate-selection. 
determination of wages (Cizre-Sakallıoglu, 1991). This, in turn, became a prescription for high unemployment and stiff competition for a place in the large, primarily non-union, low-wage labour force, with minimal social regulation of wages and benefits. A labour force fearful of being fired 'at will' is effectively excluded from political calculations and from decisions undertaken at the level of the public sphere. In this sense, the globalization of business and finance was achieved at the expense of a reduction in the influence of labour.

Resistance by the state to criticism of public policies and social protest within the political space has also been facilitated by the deepening of divisions within the society. The concept of Turkish political parties as representative institutions with roots in society has broken down, helped along by a lack of planning and vision concerning government and responsiveness, as well as a lack of public accountability. The crisis of the political parties conflates, in a very real sense, with the crisis of conflicting paradigms and of state-society relations. This seems to be a common feature shared by new and old democracies opting for a programme of unfettered markets under global conditions. Globally speaking, just as the quest for a neoliberal mandate has meant a convergence of economic policies on the political platforms of both left and right (Öniş, 1997b: 43), so informed political debate in the public sphere is retarded by the absence of ideas, values and objectives as bases for conciliation and integration - which is, after all, what politics is all about. Thus, one reason for the insulation of Turkey's political class and politics from democratic pressure is the qualitative shrinkage of the political sphere.

Effective politics is not based on, nor does it revolve around, a fundamental agreement; it is in fact made possible by the absence of consensus. Politics, in other words, aims to generate a common meaning by subjecting the key issues to public debate on the basis of differing ideas and values held by diverse groups:

firstly, because they have a common interest in sheer survival and, secondly, because they practice politics - not because they agree about 'fundamentals', or some such concept too vague, too personal, or too divine ever to do the job of politics for it. The moral consensus of a free state is not something mysteriously prior to or above politics: it is the activity of politics itself. (Crick, 1966: 24)

Politics in Turkey, however, does not fit this characterization. According to Çinar (1997: 72): 'all key issues are accepted without debate. The only competition is over "who" will implement the policies. It has thus become increasingly difficult to distinguish among the parties, except for their leaders. Turkish politics, in reality, has been reduced to administration'. The diminished potential of the public/political space to influence public policy is, therefore, one aspect of the shrinking realm of the political, in a physical and qualitative sense. This seems to be a widely shared global reality:

What's confounded American liberalism and European social democracy is that the very realm of the political has shrunk. The welfare of the poor, the maintenance of the infrastructure, 
the health of the populace - these are increasingly the province of the market now; no political solutions need apply. The center-left parties in many nations will cling to office ... but genuine power will elude them until politics and government become as transnational as the economy. (Meyerson, 1997: 32)

A seasoned politician of the right, Korkut Özal (brother of the former president Turgut Özal) has summed up the popular feeling on the changed structure of politics, claiming that neither the leaders nor the masses nor the parliament wield real power. The Turkish system has become a combination of statism and crony-capitalism in which economic, political and social rents are shared among 'domestic and international businesses, subcontractors who deal with the state... mafia groups ... drug and gun smugglers'. ${ }^{18}$

Given the historical setting of a powerful military which has staged coups and issued ultimata to the democratically-elected governments of Turkey since $1960,{ }^{19}$ one of the most important causes for the weakened and restricted political sphere is undoubtedly the political role of the Turkish military. Its political effectiveness stems from a combination of factors, the chief one being its historical-cultural context: as the founding institution of the Republic, the military sees itself as the guarantor of last-resort of the national interest which is defined - with differing emphases at different times - as confronting reactionary Islam, ethnic secessionism, and the communist challenge. The Turkish military can be said to have a 'political autonomy' (see Cizre-Sakallıoglu, 1997: 151-66), an ability to go above and beyond the constitutional authority of elected governments to uphold the precepts of the state ideology known as Kemalism.

The political role of the military imposes limits on Turkish democracy in a kind of vicious circle: the current constitutional structure, for instance, is a legacy of the last military coup of 1980 which constructed the future ideological and institutional norms of Turkish politics in a restrictive and state-dominated fashion. Post-1980 arrangements narrowed the bases of political participation, abolished existing political parties, banned their leaders from political activity, and strengthened state institutions, weakening in the process the foundations of parliamentary democracy. The pattern of politics established by military rule thus paved the way for the crisis of political parties as representative institutions capable of formulating policies responsive to popular demands. The fact that the Turkish political stratum fails to respond to its constituency can be traced back to the restricted

18. Interview with Korkut Özal, 'Başbakanı Sonbahara Seçelim' (Let's Elect the Prime Minister in Fall), Milliyet, 23 June 1996.

19. In 1960 and 1980, the military staged coups to overthrow the existing governments on the grounds that they had basically failed to safeguard order and unity. On two occasions (12 March 1971 and 28 February 1997) the military issued ultimata to the existing governments to dispel public disorder and/or restore the secular character of the Republic. In both cases, the existing governments stepped down from power. 
parameters of the political sphere, in which they do not have the freedom to move effectively. None the less, this failure in turn becomes the occasion for more military whistle-blowing and for further reconfigurations of politics. At the same time, the inability of civilian actors to relegate the military to a politically subordinate position in the system is reproduced and prolonged.

It is true that the ' 28 February process' (the name given in Turkey to the aftermath of the military's last intervention, in 1997) follows, on major lines, the tradition of the military as guarding the secular pillars of the Republic. The military's argument is that, in the absence of stable and effective government, Islamic 'fundamentalism' has become the gravest danger to the survival of the secular Republic. There is, however, a fundamental difference between the military's past involvements in politics and the present one: the Turkish military has historically resisted involvement in the 'daily' conduct of politics for fear that it would damage its image as an entity 'abovepolitics'. Furthermore, in the past, it flexed its political muscle through the constitutional platform of the National Security Council and without blurring the civilian-military boundaries (Pinkney, 1990: 98). Since 28 February 1997, however, the political profile of the army has risen to great heights; it has acquired a more visible role and greater autonomy in key political areas, and has become actively involved in day-to-day politics, illustrated by its opposition to any deal or formula that would bring the Virtue Party, successor of the Welfare Party, to power. ${ }^{20}$ As the military tries to reconfigure Turkish politics within the secular parameters it has unilaterally set, democracy is reduced to a series of power games devoid of representative or responsive potential. Government authority is not only subordinated to the interests of the dominant fraction of capital, but also to the political terms set by the military.

There are, however, both pluralist and monistic features articulated by the regime: civil society has some latitude but no real strength; the parliament contains oppositional forces but has no real authority; the judiciary operates with some independence at times but is by and large politically controlled; the media can uncover the dark connections between organized crime and state security forces, ranging from unknown murders to drug smuggling, but is itself oligopolistically owned and prone to using nationalist and populist influences to sway the people. The ability of civilians to control the military is weak, but the polity is not a military regime. While most people, given the chance, would opt for Western standards of living, globalization has weakened the equitable delivery by the state of the requirements behind those standards. These contradictory components make an unambiguous characterization of

20. This became quite clear during the search for an interim government, after the collapse of the Yilmaz government on 25 November 1998. The search ended when the veteran centreleft leader Bulent Ecevit formed a government on 11 January 1999. 
the Turkish political system difficult. The public sphere is clearly weak and ineffective, but the political class which wields power observes enough democratic procedures not to be considered totally undemocratic.

\section{LEGITIMATION OF THE ECONOMIC AGENDA IN THE 1990s}

Moving into the next millennium, the fundamental problem faced by Turkish neoliberalism is how to maintain the legitimacy of the political system against a backdrop of high inflation, high unemployment, Mafia-state connections, the socio-economic deprivation of many, and a narrow, sterile and discredited political life. While the imperative of global financial integration has threatened the policy autonomy of the government, it has also increased enthusiasm for the market. The inabilities of the state to achieve sustainable economic development and political confidence cannot therefore be attributed entirely to global interdependence: domestic variables are central to understanding how the regime's economic choices are made acceptable to the citizens. Ultimately, this hinges on the ability of the system to meet the expectations of its citizens.

In attempting to give political legitimation to the neoliberal agenda of the 1990s, four mechanisms can be distinguished: (i) the politics of a haemorrhaging public sector; (ii) the role of the informal sector and the rise of the so-called Anatolian Tigers as new patterns of capital accumulation; (iii) promotion of the market; and (iv) antipolitical politics and reform populism.

\section{The Politics of a Haemorrhaging Public Sector}

Draining of scarce public resources by a ballooning public debt contributes to both the delegitimation and legitimation of the political system at one and the same time. It helps to delegitimize the system by increasing the inflationary pressures stemming from the budget deficit. However, as a symptom of the strong populist current which has become a persistent feature of Turkish politics, it has also acted as an integrative mechanism in society. In much of the pre-neoliberal era of import substitution development, which characterized the period 1963-80, the traditional democratic discourse was centred on the public sector manipulation of an 'electoral' rather than a 'democratic' form of capitalism. In the historical context of a state-dominated economy, politics was understood and defined as a strategy to build and sustain power by distributing material benefits generated by the state through clientelistic channels of interest mediation, with political parties and corporatist unions being two prominent organizations. Distribution of state largesse to the voters, to undermine their opposition, sustained a deficit-prone economy. Politically, however, it has retarded the 
ideological content of the political parties. It has become a manifestation of 'democracy deficit', of the lack of self-confidence of Turkey's political élite who have to lean on the tradition of populism used by their predecessors to make the social and political order work. Eighteen years after transition to a pro-market model, the political class is still unwilling to relinquish its 'power'. It continues to maintain a large public sector, as the massive budget deficit of 1998 shows. Distribution of state largesse ranges from offering high agricultural support prices to producers, to providing employment opportunities in state-controlled sectors, and to announcing generous salary adjustments for public sector employees on the eve of general elections.

Another hangover from the pre-1980 days is the substitution of internal borrowing for increased share of tax revenue in GNP. As discussed above, the benefits of the financial reform were cornered by the public sector in Turkey, which became a bastion of privilege as the state assumed a regulatory role in the creation and appropriation of economic surplus. Especially after 1987, 'governments preferred to borrow from the growing domestic financial markets rather than undertaking tax and social security system reforms' (Tükel, 1997: 27). Thus, it is not democratic norms and institutions that constitute the common conception of legitimacy of the state, but the instrumental role of public spending which produces moral, economic, and political sustainability. It is the continuing absence of a democratic substance/ tradition in Turkish politics, of the kind found in Western liberal tradition, that is largely responsible for the fever of public sector borrowing and the ensuing pressures of macroeconomic crisis and continued inflation.

\section{Economic Growth, the Informal Sector and the 'Anatolian Tigers'}

Concomitant with the deepening fragmentation and severe marginalization of labour, the 1990s have also witnessed the rise of an informal private sector development, mostly based on small-scale, family enterprises in selected Anatolian towns, such as Denizli, Gaziantep and Şanlı Urfa. The underlying logic of these ventures is their self-reliance and ability to "establish themselves as significant exporters of manufactures, while at the same time receiving little or no subsidy from the state' (Öniş, 1997a: 759). These units have been hailed a success story by the media, which has labelled them the 'Anatolian Tigers', reflecting the 'generally shared positive sentiments about their economic potential' (Buğra, 1997: 50).

Part of the economy's ability to sustain a high growth pattern under conditions of prolonged macroeconomic instability comes from the robust economic activity in these centres. Although comprehensive statistics are not yet available on the size and nature of the production processes carried out by the 'Tigers', there is much anecdotal evidence, supported by panel data and surveys, that these enterprises can be seen as part of the rapidlyexpanding 'flexible production system'. This system is based on small but 
effective production units with the capability of adapting to changing market conditions, both domestic and abroad. ${ }^{21}$

A significant characteristic of these firms is that they hire mainly unskilled, unorganized (marginal) elements of the labour force, for low pay. According to a recent survey by Köse and Öncü (1998), based on 590 smallscale manufacturing enterprises in four Anatolian provinces, 65 per cent of the employed workers were unskilled, and 94 per cent had only primary school education. A mere 1 per cent received union-wages, underscoring the extent of poverty and marginalism in the system of industrial relations characterizing the 'Anatolian Tigers'. Among the employers themselves, 46 per cent were reported as having only primary schooling, with only 15 per cent having a college degree or equivalent. Based on their sample, Köse and Öncü report that hierarchical family rule is the main managerial system in these enterprises, with only 14 per cent having managers on wages and salaries.

These findings clearly signal, in the words of Buğra (1997: 53): “"a strategic fit" between the traditional institutions that regulate social relations and current requirements of global production and trade' - in other words, between these institutions and the characteristics of flexible production systems. This 'fit' informs much of the basic rhetoric of the principal association of Islamic business interests in Turkey, the Independent Association of Industrialists and Businessmen (MÜSIAD). Founded in 1990, MÜSİAD grew rapidly to include around 3000 member companies, and became the leading representative of small and medium-sized firms from various regions. The promotion of small-scale units based on Islamic business ethics and 'just remunerations' for workers constitutes the major organizing theme of the MÜSIAD perspective. There are in fact many parallels between the MÜSIAD's criticisms of what it considers to be the 'now outmoded industrial society', and the 'just order' manifesto of the now-banned Welfare Party, based on anti-Western rhetoric. ${ }^{22}$

Politically, then, it is possible to see the advent of the Anatolian Tigers and the Islamic bourgeoisie as part of the larger process of structuring production into a global core-periphery model. As such, this development can be said to achieve three basic objectives. Firstly, by fragmenting labour it further weakens the power of organized labour and strengthens the position of capital within the production process. Secondly, the shift from economies of scale to economies of flexibility makes business less controllable. The Anatolian Tigers thus accelerate the globalization of production

21. For instance, according to a survey conducted jointly by the State Planning Organization (SPO) and the State Institute of Statistics (SIS) in 1997, 95 per cent of manufacturing firms in 1994 employed less than ten workers, generating 35 per cent of total manufacturing employment, and producing 6 per cent of its total value added.

22. See, for example, Yarar (1996) for a general exposition of the MÜSIAD's perspective on industrial relations. 
in Turkey and facilitate the mobility of global capital: in that sense, they collaborate with the international system. Thirdly, as Anatolian Tigers are linked with Islamic capital, they represent a haven for the electoral force of the Virtue Party (VP); that is, they are not only interested in a 'critique' of the existing order but are willing to battle against the profound and destructive societal dislocations caused by the partial move from a regulated to a market economy.

Operating in 'informal' activities in commercial and service sectors where entry barriers and incomes are low, and living in sprawling squatter settlements, Turkey's informales (the metropolitan poor) can be regarded as taking their revenge on the system by causing a painful and profound dislocation in Turkish politics. This revenge has two aspects: on the one hand, the urban poor have become the basis of an increasingly unpredictable electorate, exacerbating the difficulties of a political class already lacking in confidence. On the other hand, the withdrawal of the support of the informales, together with the estrangement of the professional urban strata from centre-right and centre-left parties, has contributed to the erosion of the power of the centre which is mistakenly linked to 'its fragmentation' (Çınar, 1997: 73).

Articulating a lifestyle based on a complex web of personal ties with global images, the city poor and the middle classes maintain unstable linkages to political parties and highlight the exhaustion of the centre-left and centre-right. Surprisingly, the major party of the 1980s, the Motherland Party (MP) had both contributed to the rise of this group and built a base of support among them by promising to integrate them into popular capitalism and impending prosperity. By the end of the decade, however, social ravages, high inflation and the absence of a social policy had led to the defeat of the MP in the polls. The rival centre-right party, the True Path Party (TPP), tried to appeal to the metropolitan poor with the welfarist discourse of Süleyman Demirel, its unchallenged leader until he was elected President of the Republic in 1993, upon the sudden death of the incumbent president Turgut Özal, the former leader of the MP. The urban middle classes and the poor had become too important for any political party to ignore. However, the 1993-5 coalition government of the TPP and the centre-left Social Democrat Populist Party (SDPP), under the premiership of Tansu Çiller, departed from the earlier welfarist discourse of Süleyman Demirel. The failure of the Çiller government to deliver a widely-shared prosperity led it to switch to a conservative nationalist discourse. The Islamist Welfare Party (WP) filled the vacuum and wrested power from the centre-right in the 1995 elections.

With 21 per cent of the votes cast in the December 1995 elections, the WP led a coalition government formed with the TPP on 8 July 1996. This coalition government lasted less than a year and ended with a 'soft coup', in which the military issued a 20-point ultimatum on 28 February 1997. In this ultimatum, the military reiterated its position as the guardian of the 
fundamental principle of the Republic, secularism - the exclusion of a state-defined religion from the official sphere. In a state-centred political configuration, however, separating religion and state has not been easy. The concept of secularism 'has become a designation for the ruling groups' (Yavuz, 1997: 64). It has subordinated religion in the political realm, overlapping in turn with cultural cleavages in the society between 'modern versus traditional, progressive versus conservative, and rationalist versus religious' (ibid.). After the intervention of 28 February, the chasm separating Turkey's secularists and Islamists widened. The WP, with the Virtue Party as its ardent follower, became the only voice in politics to respond to problems of inequity; but this is not to suggest that the WP can be reduced to an expression of socio-economic disparities. It has come to represent a 'larger Islamic social movement that seeks to reconstruct many traditional aspects of society from cuisine to political exchanges' (Yavuz, 1997: 65). The root cause of the WP's rise is that, in the absence of significant leftist policies, the existing critique of the status quo is translated into Islamic politics: 'Witness the metropolitan poor, who are unlikely to have undergone mass religious conversion, yet who switched their electoral allegiance from Social Democrats to Islamists' (Mango, 1997: 10). The problem with the growing power and appeal of the Virtue Party, however, is that it increases polarization in the society between secular/Westernized Republicans and proIslamic forces.

\section{Seductiveness of the Market}

The disappearance of political ideas and consequent enfeeblement of the public sphere, wherever it might happen, has ramifications. In the words of Bauman (1991: 41, 42):

impoverishment of the public sphere boosts the search for and the seductive power of private escapes from public squalor ... Above all, system-generated discontents are as subdivided as the agencies and actions that generate them. At most, such discontents lead to 'single-issue' campaigns that command intense commitment to the issue in focus while surrounding the narrow area of attention with a vast no-man's land of indifference and apathy.

Since politically ineffective discontent cannot translate into a subversive force, the state, given the contemporary global agenda of neoliberalism, 'by and large cedes the integrative task to the seductive attractions of the market' (ibid.: 43).

'The hollowing out of politics' (Boron, 1996: 330) is intertwined with market utopias sustained by new populist formulas. Indeed, the seductive power of the market seems to rest upon a new social base largely consisting of the informales and the middle classes in a context of weakened representative institutions, socio-economic stress and a minimal political role for citizens. One key instrument enhancing the seductive appeal of the market in the 1990s is the consumer boom. Many Turks are enjoying their 
first access to personal credit cards, car loans and expanded sources of consumer credit which were encouraged by the financial liberalization of 1989. It was reported in 1997 that there were 8.5 million Visa cards in Turkey, constituting 7.5 per cent of the total available cards in Europe, and accounting for 2.6 per cent of the total volume of transactions. ${ }^{23}$

The ways in which the mass media articulate with politics reinforces the 'hollowing out' process by either trivializing the real political issues that underlie the rhythms of daily life or by dramatizing and publicizing the trivial/unpolitical/private. Apart from suggesting a refinement of the critical issues, the kind of social criticism offered by the media falls within the familiar parameters of official politics. The mass media, on the whole, contributes to the detachment of political demands from appreciations of socioeconomic conditions.

\section{Antipolitical Politics and Reform Populism}

The political expression of the seduction of the market is the politics of antipolitics; for some, this is a revived and transformed version of the classical populist strategy of creating local bases of clientelist support, under a market-led growth model (Roberts, 1995: 98). Antipolitics takes the form of continual attacks on traditional politics, institutions, actors, and political culture by the political class, intellectuals and the general public. As a trend of thinking and a style of politics which is found in all contemporary Western democracies, antipolitics draws strength from the organizational and ideological failure of political parties (Poguntke, 1996: 324; see also von Beyme, 1996), and the ready identification of democracy with the ballot-box rather than within the constitutional framework of struggling democracies. ${ }^{24}$ Anti-establishment messages exploit popular disillusionment with established institutions and with the economic outcomes of the neoliberal model. They also enable personal leaders to establish vertical, unmediated relationships with atomized masses in a fragmented civil society (Roberts, 1995: 113-15), further weakening the democratic ethos.

Perhaps the most antipolitical stand of all, reflecting the appeal to globalism to solve local problems, is the attempt to link the legitimacy of a series of governments beginning with the initial phases of Turkish neoliberalism in the 1980s to the 'efficiency of a managerial state', rather than to the expansion of democracy and concern for the rule of law. The promotion of democracy has become an instrument which enables post-1980 governments

23. Enis Berberoğlu, 'Global Ortaklık, Yerel Demokrasi' (Global Partnership, Local Democracy), Hürriyet, 27 November 1997.

24. For the application of an antipolitical discourse in the True Path Party of Turkey, see Cizre-Sakallığlu (1996). 
to create a positive environment for a global agenda, rather than a means to appropriate a meaningful programme of public accountability and social justice. The real focus has been on centricist, pragmatic, simple 'technical' solutions to complex problems. In subordinating politics to the technical/ economic logic of neoliberalism, governments have relied on what one writer calls the "satanizing discourse of the state for all the misfortunes and mishaps' (Boron, 1996: 309). By equating 'the entire state with inefficiency, corruption and squandering' (ibid.: 310 ), this discourse attributes opposite characteristics to private initiative and legitimizes the free-market paradigm.

One of the most notable manifestations of an antipolitical discourse in Turkish politics is the adoption by all political platforms, be they centre-left, centre-right, ultranationalist or pro-Islamic right, of a reform/change/renovation populism, in an attempt to stem the erosion of public confidence in the system. Promising, in vague terms, to reform the system guards against the possibility of a popular backlash in favour of a more radical alternative. The most striking example of such a reform discourse which uses technical, unpolitical vocabulary is the anti-inflationist rhetoric shared by all platforms.

Maintaining an anti-inflationary stance is regarded as vital if neoliberal policies are to appeal to low-income groups who bear the brunt of high inflation. Ironically, however, it is the failure of successive governments to control inflation that has allowed newspaper columnists and political leaders to project inflation as a matter of 'national interest', virtually of life and death. ${ }^{25}$ The issue took on new significance at the beginning of 1998, when the inflation rate hit 101 per cent in January. However, the high social costs of orthodox anti-inflationary policies proved to be a political liability for the Yllmaz-led coalition government, which had declared war on inflation when it took office in June 1997. Although he had earlier shown unprecedented sensitivity to this issue, Yilmaz reportedly rejected the IMF's suggestion that he should bring down the rate of inflation by implementing a one-year shock therapy of structural reform and fiscal discipline, saying that he had no intention of following in the footsteps of former Israeli Prime Minister Simon Peres. ${ }^{26}$ More recently, Yilmaz defended his stand in terms of the waning of popular support for strong anti-inflationary measures:

It is not possible to reduce inflation to the level we wish to see this coming year. If this coalition continues, Turkey will be a country with an inflation rate of 3 per cent in the year 2000 ... Our people have been patient with inflation. We know that especially those with limited income have reached the limits of their patience. ${ }^{27}$

25. Ertuğrul Özkök, 'Ekonomi Mehdi'sini Bekliyor' (The Economy Awaits its Mehdi), Hürriyet, 28 November 1997.

26. Simon Peres lost an election after reducing the inflation rate from around 500 per cent to below 10 per cent. For Yılmaz's thoughts on this, see Ertuğrul Özkök, 'Ben Simon Peres Olmam' (I Will Not Be Another Simon Peres), Hürriyet, 26 November 1997.

27. 'Yllmaz Enflasyondan Umudunu Kesti' (Y1lmaz Lost His Hope of Reducing Inflation), Milliyet, 7 February 1998. 
Thus the perceived structural inability of the system to recreate a widelyshared prosperity and political peace is complemented by a lack of political will, for fear of losing popular support in an impending election.

One crucial development in the second half of the 1990s, which pushed the legitimization question to the forefront of the reform agenda, was the awakening of public awareness of the criminal triangle formed by politicians, mafia bosses, and security forces. ${ }^{28}$ Yet, while 'cleaning' the state institutions has become the most important discourse for enhancing the legitimacy of the political system, the centralist and restrictive legacies which shape Turkish politics inhibit actual reform. This was clearly illustrated when Yllmaz's own government was brought down on charges of corruption. More importantly, Turkey's political class does not want to lose the benefits it reaps from the system as it stands, nor does it have the power necessary to instigate such change: 'there is a consensus on the diagnosis, a consensus on prescription, and overwhelming public support for reform. But there is no mechanism to translate this into reality' (Smith, 1999). Although it seems that public trust in the political system can be restored if substantive political reform is enacted, effective reforms can only be made by effective political players operating within an effective, democratic political space.

\section{CONCLUDING COMMENTS}

The Turkish experience in the post-financial reform period reveals a process of adjustment in which a developing market economy has become trapped by the needs of domestic industry to integrate with world markets. Confronted with the distributional imperatives of such a reorientation, the state apparatus became the dominant agent regulating income redistribution within the society. Some of the facets of this process included the declining profitability of the state economic enterprise system because of regulated pricing; a lenient and expansionary fiscal policy; suppression of wage incomes to control workers' demands; and a relatively lax attitude towards taxing corporate incomes. The fiscal requirements of these actions were financed through the newly-emerging financial instruments in an increasingly unregulated financial market. Consequently, the government's debt instruments dominated the financial markets and led to a redistribution of economic surplus to the rentiers.

28. This relationship became public knowledge as the result of a traffic accident on 3 November 1996 near Susurluk, a small town in northwestern Turkey, in which a top official of the security forces and a fugitive of the underworld died, and a Kurdish tribal leader/deputy of the parliament was injured. Public anger at the revelation of these shady connections turned into an avalanche of societal pressure to reform the organs of the state engaged in illegal activities. The intensity of the outcry for public reform lent an urgency to the efforts of Yilmaz's coalition government to uncover criminal linkages, and to arrest a number of mafia leaders. 
The delicate balance upon which this 'administered financial liberalization' rests, however, led to a reversal of incentives away from the productive sectors and physical capital accumulation in favour of speculative wealth accumulation with low propensities to invest. Thus, after two decades of structural adjustment, Turkey is entering the new millennium with erratic rates of real growth and investment, a worsened income distribution, and a paralysed fiscal apparatus.

The most visible signs of political stress in the 1990s have been the disappearance of coherent alternative political philosophies and genuine competition in the political market, with the ensuing distrust and disaffection on the part of the masses. The economically weaker segments of society have further been sub-divided into distinct rival identities based on ethnicity and religion, reflecting economic resentment against the nation-state, in a manner reminiscent of the role played by social class in earlier periods. The state has adopted a number of different dynamics to legitimize its praxis and reconstitute its social base among the numerically large informales. The defining feature of these integrative mechanisms, however, is their antipolitical character which subordinates politics to the imperatives of a global agenda. Thus, the political arena has become a playground for the military and for financial powers, further contributing to the detachment of politics from society. The problem is that it is not clear how macroeconomic instability can be corrected in the face of a narrow, sterile and discredited political life.

\section{REFERENCES}

Akyüz, Y. (1990) 'Financial System and Policies in Turkey in the 1980s', in T. Aricanli and D. Rodrik (eds) The Political Economy of Turkey, pp. 98-130. London and New York: Macmillan.

Atiyas, I. (1995) 'Uneven Governance and Fiscal Failure: The Adjustment Experience of Turkey', in L. Frischtak and I. Atiyas (eds) Governance, Leadership, and Communication: Building Constituencies for Economic Reform, pp. 223-51. Washington, DC: The World Bank.

Balkan, E. and E. Yeldan (1998) 'Financial Liberalization in Developing Countries: The Turkish Experience', in R. Medhora and J. Fanelli (eds) Financial Liberalization in Developing Countries, pp. 129-55. London and Basingstoke: Macmillan.

Barro, R. (1989) 'The Ricardian Approach to Budget Deficits', The Journal of Economic Perspectives 3(2): 37-54.

Bauman, Z. (1991) 'Living without an Alternative', The Political Quarterly 62 (JanuaryMarch): 35-44.

Bernheim, D. (1989) 'A Neoclassical Perspective on Budget Deficits', The Journal of Economic Perspectives 3(2): 55-72.

von Beyme, K. (1996) 'Party Leadership and Change in Party Systems: Towards a Postmodern Party State', Government and Opposition 31: 135-59.

Boratav, T. and E. Yeldan (1995) 'The Turkish Economy in 1981-92: A Balance Sheet, Problems and Prospects', METU Studies in Development 22(1): 1-36.

Boratav, T., K.O. Türel and E. Yeldan (1996) 'Dilemmas of Structural Adjustment and Environmental Policies under Instability: Post-1980 Turkey', World Development 24(2): 373-93. 
Boron, A. (1996) 'Governability and Democracy in Latin America', Social Justice 23: 303-37.

Buğra, A. (1997) 'The Claws of the Tigers', Private View 1(2): 50-5.

Crick, B. (1966) In Defence of Politics. London: Pelican Books.

Çınar, M. (1997) 'Mission Impossible?', Private View 1(2): 72-8.

Cizre-Sakallığlu, Ü. (1991) 'Labour: The Battered Community', in Metin Heper (ed.) Strong State and Economic Interest Groups: The Post-1980 Turkish Experience, pp. 57-69. Berlin and New York: Walter de Gruyter.

Cizre-Sakallığlu, Ü. (1997) 'The Anatomy of the Turkish Military Autonomy', Comparative Politics 29(2): 151-66.

Cizre-Sakallığlu, Ü. (1996) 'Liberalism, Democracy and the Turkish Centre-Right: The Identity Crisis of the True Path Party', Middle Eastern Studies 32: 142-61.

Eisner, R. (1989) 'Budget Deficits: Rhetoric and Reality', Journal of Economic Perspectives 3(2): 73-93.

Habermas, J. (1989) The Structural Transformation of the Public Sphere: An Inquiry into a Category of Bourgeois Society, translated by T. Burger and F. Lawrence. Cambridge, MA: MIT Press.

Hürriyet (various issues) daily newspaper, Istanbul.

IMF 'IFC Financial Statistics' (various years). Washington, DC: International Monetary Fund. Jessop, B. (1990) State Theory: Putting the Capitalist State in its Place. Oxford: Polity Press.

Kasnakoğlu, Z. (1997) 'Who Gets What', Private View 1(2): 56-62.

Köse, A. and A. Öncü (1998) 'Anadolu Sermayesi Uzerine Gözlemler' (Observations on the Anatolian Capital) Proceedings of the 9th Congress on Industry. Ankara: Chamber of Engineers (January).

Kumcu, E. (1997) 'Prospects for the Economy in 1998', Private View 1(2): 30-6.

Mango, A. (1997) 'Testing Time in Turkey', The Washington Quarterly 20 (Winter): 3-20.

Meyerson, H. (1997) 'Can Liberalism Survive Clinton - The Crisis of the "New" Center', Dissent 44(4): 27-32.

Milliyet (various issues) daily newspaper, Istanbul.

Offe, C. (1997) Varieties of Transition. Cambridge, MA: MIT Press.

Oyan, O. (1997) 'Degisen Dunya'da Degismeyen Devlet mi?' (Is State Unchanged in a Changing World?) Ekonomide Durum 3(4): 10-25.

Önis, Z. (1997a) 'The Political Economy of Islamic Resurgence in Turkey: The Rise of the Welfare Party in Perspective', Third World Quarterly 18(4): 743-66.

Öniş, Z. (1997b) 'Democracy, Populism and Chronic Inflation in Turkey: The PostLiberalization Experience', Yapı Kredi Economic Review 8 (June): 38-50.

Pinkney, R. (1990) Right-Wing Military Government. London: Pinter Publishers.

Poguntke, T. (1996) 'Anti-Party Sentiment - Conceptual Thoughts and Empirical Evidence: Explorations into a Minefield', European Journal of Political Research 29: 319-43.

Richburg, B. and S. Mufson (1998) 'In Hindsight, Signs of Asian Crisis Appear Clear', Washington Post (4 January).

Roberts, K. (1995) 'Neoliberalism and the Transformation of Populism in Latin America The Peruvian Case', World Politics 48: 82-115.

Smith, R. Jeffrey (1999) 'Despite Pressing Needs, Real Reform in Turkey Will Have to Wait', Washington Post (11 January).

Sonmez, M. (1998) 'The Story of Eastern and Southeastern Turkey', Private View 2(6). 54-64.

State Institute for Statistics (SIS) 'Households, Labour Force and Income Distribution Surveys' (various years). Ankara: SIS (see also http://www.die.gov.tr).

State Planning Organization (SPO) 'Main Economic Indicators' (various years). Ankara: SPO (see also http://www.dpt.gov.tr).

State Planning Organization (SPO) (1998) Ekonomik ve Sosyal Gostergeler (1950-1997) (Economic and Social Indicators 1950-1997). Ankara: SPO.

State Planning Organization (SPO) and State Institute of Statistics (SIS) (1997) The Census of the Denizli Manufacturing Industry (in Turkish). Ankara: SPO/SIS.

Strange, S. (1986) Casino Capitalism. Oxford: Basil Blackwell. 
Tükel, H. (1997) 'Waiting for Macroeconomic Stability', Private View 1(2): 24-8.

Undersecretariat of Treasury and Foreign Trade (UTFT) 'Main Economic Indicators' (various issues). Ankara: Undersecretariat of Treasury and Foreign Trade (see also http:// www.treasury.gov.tr)

Undersecretariat of Treasury and Foreign Trade (UTFT) 'Monthly Statistics' (various issues). Ankara: Undersecretariat of Treasury and Foreign Trade (see also http://www.treasury.gov.tr)

Verbon, H. and F. van Winden (eds) (1993) The Political Economy of Government Debt. Amsterdam: North-Holland.

Yarar, E. (1996) 21. Yüzylla Girerken Dünyaya Yeni Bir Bakış (A New Look at the World As We Enter the 21st Century). Istanbul: MSIAD.

Yavuz, H. (1997) 'Political Islam and the Welfare (Refah) Party in Turkey', Comparative Politics 29(4): 63-82.

Yeldan, E. (1997) 'Türkiye Finansal Serbestleștirme Deneyimi' (Financial Liberalization Experience of Turkey), Petrol-İS Almanac, 1995-7 (Istanbul).

Yeldan E. (1998) 'On Structural Sources of the 1994 Turkish Crisis: A CGE Modelling Analysis', International Review of Applied Economics 12(3): 397-414.

Yentürk, N. (1996) 'Impacts of Capital Flows on Saving and Investment: A Comparison of Turkey and Latin American Countries', METU Studies in Development 23(1): 151-69.

Yentürk, N. (1997) 'Destined To Be In Crisis', Private View 1(2): 38-43.

Ümit Cizre-Sakallığlu is Associate Professor of Political Science at Bilkent University (06533 Bilkent, Ankara, Turkey). She is spending the 1999-2000 academic year as a Jean Monnet Fellow in the Robert Schumann Centre in the European University Institute, Florence, Italy, working on a book project. Her writings and research have focused on Turkish and Kurdish nationalisms, the military and politics both in Turkey and from a comparative perspective; the crisis of Turkey's right-wing forces; and the historical evolution of state-Islam interaction in Turkey. Erinç Yeldan is Professor and Head of the Department of Economics at Bilkent University (06533 Bilkent, Ankara, Turkey). The main focuses of his research are macroeconomic modelling, development macroeconomics and the Turkish economy. 